Journal of Agrometeorology 23 (3) : 249-256 (September 2021)

\title{
Effects of low light intensity on radiation use efficiency and productivity of tropical pulses
}

\author{
K.N. MANOJ ${ }^{1}$, M.R. UMESH ${ }^{1 *}$, N. ANANDA ${ }^{1}$ and SHANTAPPA DUTTARGANVI ${ }^{2}$ \\ ${ }^{1}$ Department of Agronomy, ${ }^{2}$ GKMS Unit \\ University of Agricultural Sciences, Raichur, Karnataka, India \\ *Corresponding Author: mrumeshagri@gmail.com
}

\begin{abstract}
Pulses have distinct morpho-physiological response under reduced sunlight. But little is known for their capacity to adapt to the level of shading encountered in crop mixtures. Field experiment was conducted to evaluate the pulses under artificial shade during rainy season at Raichur, Karnataka. Objectives were to select potential pulse crop tolerant to shade based on productivity and radiation use efficiency (RUE). Experiment was laid out in split-plot design, wherein light intensity (unshade, 50 and $75 \%$ shade) in main plots and pigeon-pea, cowpea, lablab and black-gram were in sub plots. Shade levels were created by the erection of white shade nets at 25 DAS continued upto harvest. Results indicated that irrespective of the crop more pods, grain, stover and protein yield were recorded under unshade. While, pigeon-pea and lablab were produced significantly higher yield under unshade, however, these were also well performed under 50 per cent shade over black-gram and cowpea. However, seeds crude protein was higher in shaded plants compared to unshaded. Significantly higher RUE $\left(2.22 \mathrm{gMJ}^{-1}\right)$ was recorded in pigeon-pea under 75 per cent shade and lowest in unshaded lablab $\left(0.35 \mathrm{gMJ}^{-1}\right)$ and black-gram $\left(0.40 \mathrm{~g} \mathrm{MJ}^{-1}\right)$. Results inferred that pigeon-pea and lablab were found tolerant to shade compared to cowpea and black-gram and may be suitable for crop mixtures cultivation.
\end{abstract}

Key words: Grain yield, pulses, radiation use efficiency, shade tolerance, sunlight

Light is an indispensable resource for crop growth that controls growth rate, organ development or structure, function, and behaviour. Adopt and acclimatize to the light environment is also critical to plant survival and efficiency in production. The photosynthetically active radiation (PAR) is major factor regulating photosynthesis and other physiological processes which are ultimately govern the dry matter production (Lemaire et al., 2007). In general, plants under high light intensity are known to reduce the photosynthetic rate under the shade. Selection of species that perform stable photosynthesis under various light intensities will be a greater advantage to achieve high and stable productivity in natural environments.

Farmers adopt intercropping primarily to increase their product diversity and farm income stability through the effective use of land and other resources. Pulses are known for differential tolerance to reduced light in crop combinations. Selection of these pulses in association with other crops depends on their potential growth (Pang et al., 2017). Grain yield of pulses have been reported to reduce when intercropped with cereals and other crops. The low yield in species of intercropped pulses compared to monoculture is primarily due to shading that has led to poor development of plants. The decrease in light reaching the canopy of the legume when intercropped with other plants was about 30-50 per cent of the complete incoming radiation and started about 3035 days after crop seeding (Armstrong et al., 2008). The choice of appropriate species of pulses plays a significant role in crop mixtures cultivation to achieve the maximum yield of intercropped pulses under low light intensity. The species may respond to shading stress differently in terms of morpho-physiological characters as well as yield. Pulses are grown under a shade with minimum reduction in yield also perform better in intercropping systems (Fagwalawa and Yakasai, 2013; Reza, 2005). Under tropical conditions, evaluation of different pulses based on shade tolerance capacity in turn suitability to the intercropping system was not properly documented. 
Therefore, the objectives of the present study were to test the performance of pulses grain yield to differed densities of shading, to explore responses of the morphological and physiological traits to shading and to reveal the relationship between yield performance and responses of the morphological traits under lower light shading.

\section{MATERIALS AND METHODS}

The experiment was conducted in Kharif 2014-15 and 2016-17 at Research Farm, University of Agricultural Sciences, Raichur, Karnataka, India (16²' N, $77^{\circ} 19^{\prime} 3$ $\mathrm{E}, 407 \mathrm{~m}$ amsl). The soil of the experimental site was clay texture (50.67\%) with $\mathrm{pH} 8.26$ and EC $0.18 \mathrm{dS} \mathrm{m}^{-1}$. The available soil nitrogen, phosphorus, and potassium before seeding were $245.5,34.4$ and $278.6 \mathrm{~kg} \mathrm{ha}^{-1}$, respectively. The soil organic carbon content and bulk density were $0.54 \mathrm{~g} \mathrm{~kg}^{-1}$ soil and $1.32 \mathrm{Mg} \mathrm{m}^{-3}$, respectively. The experiment was laid out in spilt plot design with three replications. Main plot treatments were light levels of 50 and 75 per cent reduction of normal light compared with no shade as control. Whereas, legume species lablab [Dolichos lablab L. Sweet] cv. HA-3, pigeonpea [Cajanus cajan(L.) Millsp] cv. TS-3R, cowpea [Vigna unguiculata (L.) Walp.] cv. KBC-2 and black-gram (Vigna mungo L.) cv. DU-1 were assigned to sub-plots.

The crops were sown on $17^{\text {th }}$ July, 2014 and $21^{\text {st }}$ July, 2016 and raised as per the crop specific package of practices recommended for the region. In 2015, experiment was vitiated due to heavy rainfall that resulted poor establishment of pulses. At 25 DAS, artificial shade was created by aluminet shade cloth coverage and maintained upto maturity. Shading nets were erected in a rectangular frame at two-meter height above the ground to ensure good ventilation and were large enough to fully cover the corresponded shaded plots. There were two light levels consisted for shade created by aluminet clothes restricted required shade as per the treatment. No shade plants were grown under natural sunlight conditions. Shading means to simulate the effect of shade and cut down the PAR at desired level without change in light quality and photoperiod. PAR reduction (50 and $75 \%$ ) inside the shade net was calculated by using the following formula (Bhagat et al., 2017)
Reduction in PAR(\%)=100 - $\frac{\text { PAR inside }}{\text { PAR outside }} \times 100$

For biometric observations, five tagged plants from the net plot area used for recording growth parameters and then were harvested separately at maturity. Yield attributes were recorded from these plants. Nitrogen content in the seeds of all the species was estimated by Kjeldahl's method. The seed protein content was calculated by $\mathrm{N}$ content multiplied by 6.25 later converted into protein yield based on seed protein content and seed yield. Canopy temperature was estimated by infrared gun thermometer at $0.6 \mathrm{~m}$ above the fully covered plant. Relative water content was estimated from 20 leaf discs collected from randomly selected plants of all the species. Relative chlorophyll content (SPAD) of leaves was estimated by using SPAD 502 Plus (Konica Minolta, Inc.)

A SunScan canopy analyzer (Delta-T Device, Cambridge UK) was used to record incident and intercepted light by individual species. Light interception (LI) across crop canopy was recorded on a clear sunny day at $11: 00$ to $14: 00$ hours. Data was collected at 15 days interval throughout growing period after 30 DAS. The daily incident PAR values were multiplied by corresponding daily LI to compute daily intercepted PAR (Tsubo et al., 2001).

Light Interception (\%)=1 - $\frac{\mathrm{I}_{0}}{\mathrm{I}_{\mathrm{t}}} \times 100$

Where,

$\mathrm{F}=$ Fraction of incident solar radiation intercepted by a canopy layer

$\mathrm{I}_{\mathrm{o}}=$ Measured incident PAR below a canopy layer

$I_{t}=$ Radiant flux density on the top of the canopy

Radiation use efficiency (RUE) was calculated as per the procedure provided by Tsubo and Walker, (2004).

$\mathrm{RUE}+\frac{\mathrm{Y} \text { biomass }}{\text { Io } \times \mathrm{F}}$

Where, $\mathrm{Y}_{\text {biomass }}$ was aboveground biomass $\left(\mathrm{g} \mathrm{m}^{-2}\right)$, $\mathrm{I}_{\mathrm{o}}$ was the flux density of the incident PAR above the crop canopy $\left(\mathrm{MJ} \mathrm{m}^{-2}\right)$ and $\mathrm{F}$ is fraction of PAR intercepted. $\mathrm{I}_{\mathrm{o}}=$ Incident light was calculated as per the procedure of FAO 56 and presented in Table 1. 
Table 1: Mean monthly weather parameters, indices and photosynthetically active radiation (PAR)

\begin{tabular}{lccccc}
\hline \multicolumn{1}{c}{ Growing period } & $\begin{array}{c}\text { Max. temperature } \\
\left({ }^{\circ} \mathrm{C}\right)\end{array}$ & $\begin{array}{c}\text { Min. temperature } \\
\left({ }^{\circ} \mathrm{C}\right)\end{array}$ & $\begin{array}{c}\text { Rainfall } \\
(\mathrm{mm})\end{array}$ & $\Sigma$ GDD $\left({ }^{\circ} \mathrm{C}\right.$ days $)$ & $\begin{array}{c}\Sigma \text { PAR } \\
\left(\mathrm{MJ} \mathrm{m}^{-2}\right)\end{array}$ \\
\hline June & \multicolumn{2}{c}{2014} & & & 144.0 \\
July & 37.8 & 24.7 & 48.4 & 636.6 & 125.4 \\
August & 33.7 & 23.1 & 123.1 & 570.6 & 221.1 \\
September & 32.7 & 22.7 & 372.9 & 548.9 & 180.0 \\
October & 31.0 & 22.5 & 102.7 & 502.4 & 292.9 \\
November & 32.0 & 21.3 & 50.6 & 516.3 & 270.0 \\
December & 30.9 & 17.5 & 12.0 & 426.1 & 252.1 \\
\hline & 29.4 & 15.1 & 1.8 & 380.2 & 140.9 \\
\hline June & & & & & 125.7 \\
July & 33.8 & 24.2 & 194.1 & 569.8 & 221.5 \\
August & 31.8 & 23.5 & 143.2 & 547.9 & 185.6 \\
September & 32.4 & 23.1 & 78.0 & 549.3 & 293.5 \\
October & 29.2 & 22.6 & 292.5 & 476.5 & 265.4 \\
November & 31.2 & 19.7 & 39.2 & 478.5 & 246.4 \\
December & 31.1 & 16.1 & 0.0 & 407.5 & 392.4 \\
\hline
\end{tabular}

\section{Statistical analysis}

The experimental data were subjected to statistical analysis adopting Fisher's method for analyses of variance as outlined by Gomez and Gomez (1984). The level of significance used in the ' $F$ ' test was given at $5 \%$. Least significant difference (LSD) values have been given in the Table 2 at $5 \%$ level of significance, wherever the $\mathrm{F}$ test was significant.

\section{RESULTS AND DISCUSSION}

\section{Weather and crop growth}

Experimental site belongs to North Eastern Dry Zone of Karnataka where tropical climate prevailed throughout the year. The germination and establishment was good due to favourable rainfall situation during early stages. Crops did not experience moisture stress as they were supplemented with irrigation during dry spells. The crop was free from major pests and diseases as necessary plant protection measures were taken. Maximum rainfall received during the cropping season in 2014 was 711.5 mm highest in August (372.9 mm) and correspondingly $755.2 \mathrm{~mm}$ in 2016 highest in September (292.5 mm) (Table 1).During crop growth period, mean monthly maximum temperature was ranged from $29.2^{\circ} \mathrm{C}$ (September) to $32.4^{\circ} \mathrm{C}$ (August) while, the mean minimum temperature ranged from $15.3^{\circ} \mathrm{C}$ (December) to $23.5^{\circ} \mathrm{C}$ (July) and found that there was no much deviation from the normal value. Maximum monthly growing degree days were recorded during June and least in December in both the seasons. However, higher accumulation of PAR was recorded during October (292.9 and 193.5 $\mathrm{MJ} \mathrm{m}^{-2}$ in 2014 and 2016, respectively) and lesser in July month (125.4 and $125.7 \mathrm{MJ} \mathrm{m}^{-2}$ ).

\section{Canopy characters}

Canopy characters were differed significantly during the crop growth period due to artificial shade levels and pulse species (Table 2).The leaf chlorophyll content of pulses was increased gradually with decreasing light levels and the maximum values of SPAD (49.2) were recorded under 75 per cent shade and lower under no shade condition (42.9). This may be due to shaded leaves are thinner and their chloroplasts larger and richer in chlorophyll than the leaves of sun plants. Total chlorophyll content tended to increase in the shaded plants (30 and $50 \%$ of normal light) and increased pigment content of shade leaves has been attributed to the increased number and size of chloroplasts, the amount of chlorophyll per 
Table 2: Leaf relative chlorophyll values, canopy temperature, relative water content (RWC), Yield attributes and grain quality of different pulses grown under artificial shade and no shade condition during rainy season (Average of two years).

\begin{tabular}{|c|c|c|c|c|c|c|c|c|}
\hline Treatments & $\begin{array}{l}\text { SPAD at } \\
50 \text { DAS }\end{array}$ & $\begin{array}{c}\text { Canopy } \\
\text { temperature } \\
\left({ }^{\circ} \mathrm{C}\right)\end{array}$ & $\begin{array}{c}\text { RWC at } 50 \\
\text { DAS }\end{array}$ & $\begin{array}{c}\text { Pods per } \\
\text { plant }\end{array}$ & $\begin{array}{l}\text { Seed yield } \\
\left(\text { g plant }^{-1}\right)\end{array}$ & $\begin{array}{l}100 \text {-seed } \\
\text { weight (g) }\end{array}$ & $\begin{array}{l}\text { Seed protein } \\
\text { content (\%) }\end{array}$ & $\begin{array}{l}\text { Protein } \\
\text { yield } \\
\left(\mathrm{kgha}^{-1}\right)\end{array}$ \\
\hline \multicolumn{9}{|c|}{ A. Shade levels (S) } \\
\hline $\mathrm{S}_{1}$ : No shade & 42.9 & 31.5 & 63.7 & 199.7 & 18.5 & 12.8 & 21.5 & 291.77 \\
\hline $\mathrm{S}_{2}: 50 \%$ shade & 46.7 & 29.5 & 69.2 & 147 & 15.7 & 13.1 & 23.76 & 260.21 \\
\hline $\mathrm{S}_{3}: 75 \%$ shade & 49.2 & 28.6 & 71.4 & 126.2 & 13.6 & 13 & 24.08 & 222.71 \\
\hline LSD (p = 0.05) & 4.2 & 1.8 & 4.6 & 18.4 & 1.8 & NS & 1.87 & 24.9 \\
\hline \multicolumn{9}{|c|}{ B. Pulse species (P) } \\
\hline $\mathrm{P}_{1}$ : Pigeonpea & 44.0 & 30.2 & 51 & 384.1 & 45.6 & 13.4 & 23.34 & 393.11 \\
\hline $\mathrm{P}_{2}:$ Cowpea & 50.4 & 29.6 & 79.8 & 45.3 & 4.6 & 10.1 & 23.45 & 237.7 \\
\hline $\mathrm{P}_{3}:$ Lablab & 44.6 & 29.3 & 74.3 & 172.7 & 12.2 & 23.2 & 23.24 & 312.71 \\
\hline $\mathrm{P}_{4}$ : Blackgram & 46.0 & 30.2 & 67.2 & 28.4 & 1.2 & 5.1 & 22.41 & 89.4 \\
\hline $\operatorname{LSD}(p=0.05)$ & 2.4 & NS & 3.9 & 22.2 & 1.5 & 0.7 & NS & 32.7 \\
\hline $\mathrm{P} \times \mathrm{S}$ & NS & NS & NS & 40.4 & 2.8 & NS & NS & NS \\
\hline
\end{tabular}

Table 3: Grain and stover yield of different pulses grown under artificial shade and no shade condition (Average of two years)

\begin{tabular}{|c|c|c|c|c|c|c|c|c|}
\hline \multirow[t]{2}{*}{ Shade levels (S) } & \multirow[t]{2}{*}{ Pigeonpea } & \multirow[t]{2}{*}{ Cowpea } & \multirow[t]{2}{*}{ Lablab } & \multirow[t]{2}{*}{ Blackgram } & \multicolumn{4}{|c|}{$\operatorname{LSD}(\mathrm{p}=0.05)$} \\
\hline & & & & & $S$ & $P$ & $\mathrm{P}$ at same level of $\mathrm{S}$ & $\begin{array}{l}\text { S at same or different } \\
\text { level of } P\end{array}$ \\
\hline \multicolumn{9}{|c|}{ Grain yield (kg ha-1) } \\
\hline $\mathrm{S}_{1}:$ No shade & 1823 & 1054 & 1578 & 629 & 127 & 111 & 207 & 206 \\
\hline $\mathrm{S}_{2}: 50 \%$ shade & 1447 & 734 & 1162 & 433 & & & & \\
\hline $\mathrm{S}_{3}: 75 \%$ shade & 1518 & 667 & 1254 & 435 & & & & \\
\hline \multicolumn{9}{|c|}{ Stover yield $\left(\mathrm{kg} \mathrm{ha}^{-1}\right)$} \\
\hline $\mathrm{S}_{1}$ : No shade & 3737 & 2063 & 4763 & 3192 & 237 & 246 & 451 & 428 \\
\hline $\mathrm{S}_{2}: 50 \%$ shade & 3576 & 1709 & 4022 & 2691 & & & & \\
\hline $\mathrm{S}_{3}^{2}: 75 \%$ shade & 3766 & 1487 & 3979 & 2652 & & & & \\
\hline
\end{tabular}

chloroplast and better grain development (Polthanee et al., 2011). Among the pulses, significantly higher SPAD values were recorded in cowpea (50.4) and lower in pigeon-pea (44).

Canopy temperature is often used to indicate vegetative water status and as indirect measure of transpiration rate and sensible heat transport from vegetation. In the present study, significantly higher canopy temperature was recorded when plants grown under open sunlight (31.5) and lower in 75\% shaded level (28.6). This might be due to higher light intensity has resulted in higher transpiration rate and lower water content of the leaves under no shade condition. Thus, relative water content of the leaves was significantly higher in plants grown under 75 per cent shaded level and the magnitude of increase was 10.78 and 3.08 per cent over plants grown under no shade condition and 50 per cent shaded level (Table 1). Similar results of reduced transpiration and stomatal conductance under shade was reported by Chauhan et al. (2013). Among the pulses the canopy temperature was found non-significant however, higher canopy temperature was recorded in blackgram (30.2) and pigeon-pea (30.2) while lower in lablab (29.3) canopy.

\section{Yield and yield attributes}

Artificial shade had significant impact on grain yield of all the species selected for the study. Species grown under no shade have out yielded over reduced light 
Table 4: Relationship of total dry matter (TDM) at harvest, light interception (LI), radiation use efficiency based on grain yield (RUEg), Normalized difference vegetation index (NDVI), relative water content (RWC), grain, stover and crude protein yield of pulses as influenced by shade levels

\begin{tabular}{|c|c|c|c|c|c|c|c|}
\hline Variable & TDM at harvest & LI & RUEg & NDVI & RWC & Grain yield & Stover yield \\
\hline TDM at harvest & 1.00 & & & & & & \\
\hline LI $\S$ & $0.773^{* *}$ & 1.00 & & & & & \\
\hline RUEg & -0.017 NS & $0.161 \mathrm{NS}$ & 1.00 & & & & \\
\hline NDVI§ & $0.538^{* *}$ & $0.718^{* *}$ & $0.315 \mathrm{NS}$ & 1.00 & & & \\
\hline RWC§ & $-0.095 \mathrm{NS}$ & $0.302 \mathrm{NS}$ & $0.199 \mathrm{NS}$ & $0.600^{* *}$ & 1.00 & & \\
\hline Grain yield & $0.919^{* *}$ & $0.752^{* *}$ & $0.105 \mathrm{NS}$ & $0.525^{* *}$ & -0.075 NS & 1.00 & \\
\hline Stover yield & $0.943^{* *}$ & $0.806^{* *}$ & $0.067 \mathrm{NS}$ & $0.651^{* *}$ & $0.028 \mathrm{NS}$ & $0.865^{* *}$ & 1.00 \\
\hline Crude protein yield & $0.898^{* *}$ & $0.755^{* *}$ & $0.202 \mathrm{NS}$ & $0.556^{* *}$ & -0.052 NS & $0.985^{* *}$ & $0.856^{* *}$ \\
\hline
\end{tabular}

*Significant $1 \% \quad * *$ Significant $5 \% \quad$ NS: Non-significant; §- Observation at 70 DAS
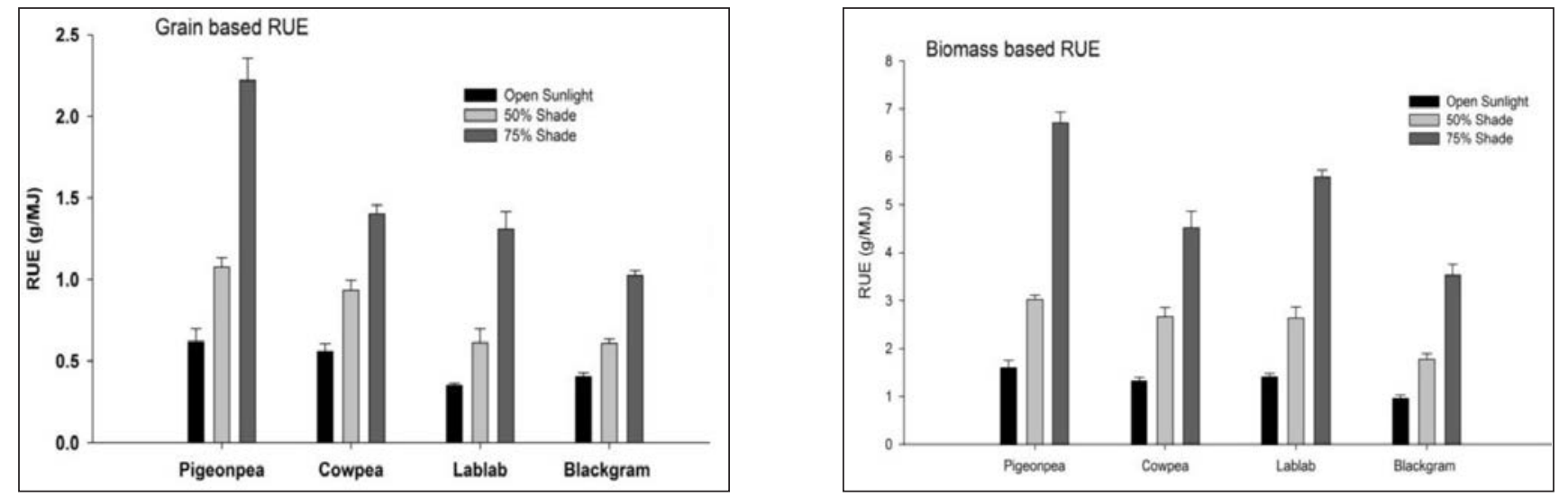

Fig. 1: Radiation use efficiency (RUE) based on grain and biomass of different pulse species as influenced by sunlight shade levels.

either at 50 and $75 \%$ shade (Table 2).The magnitude of grain yield reduction across species and shade levels was 19 to $32 \%$ over no shade. It was varied among the tested species. Higher grain yield in sunlight plants was primarily ascribed to greater leaf area and accumulation of dry matter in leaves that could have provided the reproductive components with the necessary photosynthates more effectively (Ewansiha et al., 2014). Bakhshy et al. (2013) have reported differential grain yields under no shade relative to shade

All the species have shown significantly reduced grain yield under 50 and 75 per cent shade as compared to no shade plants (Table 3). However, irrespective of shade levels pigeon-pea and black-gram recorded significantly higher and lower grain yield, respectively. This agrees with findings of Fagwalawa and Yakasai (2013) who reported that at 27 per cent reduced sunlight decreased grain yield of cowpea upto 91 per cent over no shade. Under shade severe incidence of powdery mildew was noticed despite repetitive plant protection measures as relative humidity was higher owing to constant rainfall that has resulted in reduced blackgram seed yield regardless of shade. Light had also significant effect on the biomass yield across species. It was higher in plants grown under no shade over 50 and 75 per cent shade. Significantly higher biomass was accumulated in lablab (5566 $\mathrm{kg} \mathrm{ha}^{-1}$ ) followed by pigeon-pea (4743 $\mathrm{kg} \mathrm{ha}^{-1}$ ) and least in black-gram (1124 $\mathrm{kg} \mathrm{ha}^{-1}$ ). This might be due to higher total dry matter 
production in the plant parts at harvest under no shade in lablab and pigeon-pea. Araki et al. (2014) also recorded a clear decreased stover yield of greengram owing to reduced light levels. The seed yield was governed by several direct and indirect factors of plants and weather attributes. The factors that directly affect seed yield are yield components, these include pods per plant, seeds per pod and seed yield per plant (Zhang et al.2011). Reza (2005) reported that mungbean grown under full sunlight gave higher pods per plant, seeds per pod, thousand seed weight and seed yield, while pod length was found greater in 75 per cent PAR level.

All pulses tested reported significantly $(\mathrm{p}=0.05)$ greater yield components under no shade relative to 50 and 75 per cent shade levels, except seeds per pod that were found to be higher under shade conditions. Pigeon-pea and black-gram recorded significantly greater and lower number of pods per plant, seed yield per plant regardless of shade levels. While, cowpea recorded significantly higher seeds per pod. Our results were in agreement with the findings of Zhang et al. (2011) reported that stress due to shade decreased soybean main-stem pods per plant, seeds per pod, 100-seed weight and effective branch numbers per plant, but increased branched pods per plant and seeds per plant were noticed. Fagwalawa and Yakasai (2013) also mentioned that the grain yield components in different varieties of cowpea were higher under 100 per cent light intensity followed by 40 and 20 per cent intensity. Bhagat et al. (2017) also opined that soybean genotypes were responded variedly to reduced PAR and irrigation.

\section{Radiation use efficiency}

Under field conditions the interception of the incoming PAR by leaves is a major process of biomass production. Grain yield-based radiation use effectiveness has a sign of canopy growth and the light interception and was considerably affected by artificial shade levels and pulses (Fig. 1). Higher energy accumulated in grain by way of effective utilization of radiation (RUEg) was observed in pigeon-pea grown below 75 per cent shade $\left(2.22 \mathrm{gMJ}^{-1}\right)$. It was further decreased in pigeon-pea (72 and 51\%), cowpea (75 and 58\%), blackgram (82 and 71\%) and lablab (84 and 72\%) under no shade and 50 per cent shade, respectively. This might be due to greater above ground biomass and greater fractional PAR interception during the pod filling stage. As light accessibility during pod formation would impact on pod numbers and yield attributes. The maximum seed yield was also related to RUE. However, grain yield based RUE was considerably smaller when lablab $\left(0.35 \mathrm{gMJ}^{-1}\right)$ and black-gram (0.40 $\mathrm{gMJ}^{-1}$ ) grown under no shade. The results were also with the findings of Sandana et al. (2012) who reported that intercropped beans (77\%) and groundnut (79\%) have greater RUE compared to sole crop RUE. It was mainly due to lower PAR interception by the canopy per unit of dry matter thereby improving the RUE. Mishra et al., (2009) developed relationship and reported that between dry matter production, light interception and radiation use efficiency of different wheat varieties were higher correlated.

\section{Grain quality}

The grain crude protein content was significantly influenced by artificial shade levels (Table 1). It was higher when plants are grown under 75 per cent shade (24.08\%) and lower in no shade plants (21.5\%). Whereas, under no shade, protein yield was considerably greater and lower in shaded crops at 75 percent. In no shade crops, the magnitude of enhanced protein yield was 11 and 24 per cent greater than 50 and 75 per cent shaded plants. This can be ascribed to greater manufacturing of biomass leading to greater yields of grain under no shade (Pang et al., 2017). The formidable correlation between grain yield and crude protein yield (0.97) is further evidence of this (Table 4). Protein output in pigeon-pea was considerably greater and the magnitude of increase was 40, 20, and 77 per cent, respectively, compared to cowpea, lablab, and black-gram. This was primarily due to greater pigeonpea grain yields over other plants (Olalekan and Bosede, 2010).

\section{Relationship between yield and growth, yield attributes}

The relationship between growth parameters, yield parameters, RUEg and protein yield were worked out (Table 4). Grain yield of pulses was significantly positively correlated with total dry matter at harvest $(\mathrm{r}=0.919)$ then light interception $(\mathrm{r}=0.752)$ and relative water content $(\mathrm{r}=0.6)$. Similarly, these parameters also significantly related with stover yield of pulses. However, 
radiation use efficiency of grain was not related with NDVI at 70 DAS, RWC, total dry matter at harvest and light interception. Whereas, crude protein yield was positively related with total dry matter $(\mathrm{r}=0.898)$, light interception at 70 DAS ( $r=0.755)$, NDVI at 70 DAS $(r=0.556)$, grain yield $(r=0.985)$ and stover yield $(r=0.856)$.

\section{CONCLUSION}

In the present study, pulses are susceptible to light under moderate shade condition, but the difference in yield and yield components can be noted. Pigeon-pea and lablab performed among the tested pulse species with minimal yield decrease and better shade tolerance compared to black-gram and cowpea. The shaded plants had higher RUE than the no shade and shading reduced the availability of radiant energy at the canopy surface. Therefore, these are potential pulses for intercropping with tall statured crops that offer a significant amount of shade.

\section{ACKNOWLEDGEMENT}

The authors are heartily thankful to the Department of Science and Technology, Govt. of India for financial assistance through Fast Track Young Scientist project. We are also thankful to Head and staff of Department of Agronomy, UAS Raichur for field trial facilities.

Conflict of Interest Statement : The author(s)declare(s) that there is no conflict of interest.

Disclaimer : The contents, opinions, and views expressed in the research article published in the Journal of Agrometeorology are the views of the authors and do not necessarily reflect the views of the organizations they belong to.

Publisher's Note : The periodical remains neutral with regard to jurisdictional claims in published maps and institutional affiliations.

\section{REFERENCES}

Araki, T., Thay, T. and Kubota, F. (2014). Effects of shading on growth and photosynthetic potential of greengram (V radiate L.) cultivars. Environ. Con. Bio., 52(4):227-231.

Armstrong, K.L., Albrecht, K.A., Lauer, J.G. and Riday, H. (2008). Intercropping corn with lablab bean, velvet bean, and scarlet runner bean for forage. Crop Sci., 48(1): 371-379.

Bakhshy, J.,Ghassemi-Golezani, K., Zehtab-Salmasi, S. and Moghaddam, M. (2013). Effects of water deficit and shading on morphology and grain yield of soybean (Glycine max L.). Tech. J.Engg. Applied Sci.,3(1): 39-43.

Bhagat, K.P., S.K. Bal, Yogeshwar Singh, S. Potekar, Sunayan Saha, P. Ratnakumar, G.C. Wakchaure and P.S. Minhas (2017). Effect of reduced PAR on growth and photosynthetic efficiency of soybean genotypes. J. Agrometeorol., 19 (1): 1-9.

Chauhan, S.K., Dhillon, W.S., Singh, N. and Sharma, R. (2013).Physiological behaviour and yield evaluation of agronomic crops under agri-hortisilviculture system. Int. J. Plant Res., 3(1): 1-8.

Ewansiha, S.U., Kamara, S.U. and Onyibe, J.E. (2014). Performance of cowpea cultivars when grown as an intercrop with maize of contrasting maturities. Arch. Agron. Soil Sci., 60(5): 597-608.

Fagwalawa, L.D. and Yakasai, M.T. (2013). The effect of different light intensities (\%) on the grain yield components of some varieties of cowpea ( $V$ unguiculataL.). Bayero J. Pure Applied Sci., 6(1): 35-39.

Gomez, K.A. and Gomez, A.A. (1984).Statistical procedure for agriculture research, $2^{\text {nd }}$ Ed., John Willey and Sons, New York.

Lemaire, G., Oosterom, V.E., Sheehy, J., Jeuffroy, M.H., Massignam, A. and Rossato, L. (2007). Is crop nitrogen demand more closely related to dry matter accumulation or leaf area expansion during vegetative growth. Field Crops Res., 100: 91-106.

Mishra, A. K., Tripathi, P., Pal. R.K. and Mishra, S.R. (2009). Light interception and radiation use efficiency of wheat varieties as influenced by number of irrigations. J. Agrometeorol., 11 (2):140-143

Olalekan, A.J. and Bosede, B.F. (2010). Comparative study on chemical composition and functional properties of three Nigerian legumes (jack beans, pigeonpea and cowpea). J. Emerg. Trends in Engg. 
Applied Sci., 1(1): 89-95.

Pang, K., Van Sambeek, J.W., Navarrete-Tindall, N.E., Lin, C.H., Jose, S. and Garrett, H.E. (2017). Responses of legumes and grasses to non-, moderate, and dense shade in Missouri, USA. II. Forage quality and its species-level plasticity. Agrofor. Syst., 93(1): 25-38.10.1007/s10457-0170068-7

Polthanee, A., Promsaena, K. and Laoken, A. (2011). Influence of low light intensity on growth and yield of four soybean cultivars during wet and dry seasons of Northeast Thailand. Agril. Sci., 2(2): 61-67.

Reza, T.M.B., (2005). Growth and yield of mungbean varieties as influenced by different light levels. An unpublish MS thesis, BSMRAU. Gazipur. Bangladesh.
Sandana, P., Ramirez, M. and Pinochet, D. (2012). Radiation interception and radiation use efficiency of wheat and pea under different $\mathrm{P}$ availabilities. Field Crops Res., 127: 44-50.

Tsubo, M., Walker, S. and Mukhala, E. (2001). Comparisons of radiation use efficiency of mono-/inter-cropping systems with different row orientations. Field Crops Res., 71: 17-29.

Tsubo, M. and Walker, S. (2004). Shade effects on Phaseolus vulgaris L. intercropped with Zea mays L. under well-watered conditions. J. Agron. Crop Sci., 190: 168-176.

Zhang, J., Smith, D.L., Liu, W., Chen, X. and Yang, W. (2011). Effects of shade and drought stress on soybean hormones and yield of main-stem and branch. African J. Biotech., 10(65): 1439214398. 